Article

\title{
Improved Short-Term Microbial Degradation in Circulating Water Reducing High Stagnant Atrazine Concentrations in Subsurface Sediments
}

\author{
Xinxin Liu ${ }^{1}$, Nan Hui ${ }^{2, *(1)}$ and Merja H. Kontro ${ }^{3}$ \\ 1 Instrumental Analysis Center, Shanghai Jiao Tong University, Shanghai 200240, China; xinxin.liu@sjtu.edu.cn \\ 2 School of Agriculture and Biology, Shanghai Jiao Tong University, Shanghai 200240, China \\ 3 Faculty of Biological and Environmental Sciences, University of Helsinki, 15140 Lahti, Finland; \\ merja.kontro@helsinki.fi \\ * Correspondence: nan.hui@sjtu.edu.cn
}

Received: 29 June 2020; Accepted: 5 September 2020; Published: 8 September 2020

\begin{abstract}
The triazine herbicide atrazine easily leaches with water through soil layers into groundwater, where it is persistent. Its behavior during short-term transport is poorly understood, and there is no in situ remediation method for it. The aim of this study was to investigate whether water circulation, or circulation combined with bioaugmentation (Pseudomonas sp. ADP, or four isolates from atrazine-contaminated sediments) alone or with biostimulation (Na-citrate), could enhance atrazine dissipation in subsurface sediment-water systems. Atrazine concentrations $\left(100 \mathrm{mg} \mathrm{L}^{-1}\right)$ in the liquid phase of sediment slurries and in the circulating water of sediment columns were followed for 10 days. Atrazine was rapidly degraded to $53-64 \mathrm{mg} \mathrm{L}^{-1}$ in the slurries, and further to $10-18 \mathrm{mg} \mathrm{L}^{-1}$ in the circulating water, by the inherent microbes of sediments collected from $13.6 \mathrm{~m}$ in an atrazine-contaminated aquifer. Bioaugmentation without or with biostimulation had minor effects on atrazine degradation. The microbial number simultaneously increased in the slurries from $1.0 \times 10^{3}$ to $0.8-1.0 \times 10^{8} \mathrm{cfu} \mathrm{mL}^{-1}$, and in the circulating water from $0.1-1.0 \times 10^{2}$ to $0.24-8.8 \times 10^{4} \mathrm{cfu} \mathrm{mL}^{-1}$. In sediments without added atrazine, the cultivable microbial numbers remained low at $0.82-8.0 \times 10^{4} \mathrm{cfu} \mathrm{mL}^{-1}$ in the slurries, and at $0.1-2.8 \times 10^{3} \mathrm{cfu} \mathrm{mL}^{-1}$ in the circulating water. The cultivated microorganisms belonged to the nine genera Acinetobacter, Burkholderia, Methylobacterium, Pseudomonas, Rhodococcus, Sphingomonas, Streptomyces, Variovorax and Williamsia; i.e., biodiversity was low. Water flow through the sediments released adsorbed and complex-bound atrazine for microbial degradation, though the residual concentration of 10-64 $\mathrm{mg} \mathrm{L}^{-1}$ was high and could contaminate large groundwater volumes from a point source, e.g., during heavy rain or flooding.
\end{abstract}

Keywords: Triazine; herbicide; bioaugmentation; biostimulation; Pseudomonas sp. ADP; Na-citrate; groundwater; cultivation; bacteria; fungi

\section{Introduction}

Atrazine [6-chloro-N-ethyl-N'-(1-methylethyl)-1,3,5-triazine-2,4-diamine] is a widely used herbicide in controlling weed growth. Once atrazine is applied in the surface soil, it is decomposed within a few months [1-3]. However, much less is known about what occurs to atrazine as it passes through the soil layers, e.g., during intense rainfall [1,4]. Atrazine dissipation is often slow in the groundwater environment, and half-lives typically range from hundreds of days to no degradation $[5,6]$. Atrazine and its degradation products desethylatrazine (DEA), deisopropylatrazine (DIA) and desethyldeisopropylatrazine (DEDIA) are detected in groundwater worldwide. The metabolites are harmful as long as the chlorine is attached to the molecule, while cyanuric acid is moderately 
biodegradable $[7,8]$. Atrazine dissipation in the environment has typically been associated with microbial activity, and the list of known atrazine-degrading microbes is long, including strains of the genera Pseudomonas, Shingomonas and Rhodococcus [7,9-11]. Hydrolytic, oxygen-independent atrazine catabolism by Pseudomonas sp. ADP consists of dehalogenation, $\mathrm{N}$-dealkylation, deamination and ring cleavage. Cytochrome P-450-associated oxidation has also been reported [7,12].

The factors affecting atrazine persistence in the subsurface environment are known to include microbial community composition, bioavailability, sorption/desorption, ionic and colloid-contaminant interactions in water, soil hydrological processes, transport, mobility, organic matter and chemical composition [2,12-14]. However, the relative importance of these factors in controlling atrazine transport from surface soil to groundwater, and in affecting atrazine persistence in groundwater, is not well known [2,4]. Methods for in situ remediation of aquifers contaminated with atrazine and metabolites are not available, and on request, contaminated groundwater is most commonly pumped for treating, e.g., by activated carbon filtration $[15,16]$. Atrazine with a water solubility of $33 \mathrm{mg} \mathrm{L}^{-1}$ at $25{ }^{\circ} \mathrm{C}$ spreads easily with flowing groundwater, is persistent in groundwater conditions, and low concentrations over large areas are difficult to remove $[4,6,17]$. The maximum permitted concentration of a pesticide or degradate in water is $0.10 \mu \mathrm{g} \mathrm{L}^{-1}$ in the European Union (EU) and $3 \mu \mathrm{g} \mathrm{L}^{-1}$ in the United States, while the EU limit for several pesticides and degradates is $0.50 \mu \mathrm{g} \mathrm{L}{ }^{-1}[6,18]$.

Possible methods for the microbiological in situ remediation of atrazine include natural attenuation, bioaugmentation and biostimulation. In natural attenuation, physical, chemical or biological processes in the environment dissipate the contaminant. In bioaugmentation, contaminant-degrading microorganisms are added, and in biostimulation, degradation rate-limiting nutrients are added $[19,20]$. Although the aquifer sediments of this study are known to contain atrazine-degrading microbes [21], natural attenuation was very slow at concentrations of $15-30 \mathrm{mg} \mathrm{L}^{-1}$, suggesting that the quality of organic matter and sediment chemical composition could not accelerate the chemical or microbial degradation of atrazine, but prevented bioavailability [17]. Indeed, microbial atrazine degradation in the sediments ceased at a concentration of about $57 \pm 11 \mathrm{mg} \mathrm{L}^{-1}$ (initial $100 \mathrm{mg} \mathrm{L}^{-1}$ ), most likely due to complex formation with organic and inorganic colloids, i.e., bioavailability was inhibited [21-23]. In addition to organic matter such as peat, other methods that could accelerate atrazine chemical dissipation include advanced oxidation processes (AOPs), using oxidants or catalysts such as iron (zero valent iron $\mathrm{ZVI}, \mathrm{Fe}^{2+}, \mathrm{Fe}^{3+}$ ), $\mathrm{H}_{2} \mathrm{O}_{2}$, ozone, sulfate or photocatalysis $[15,17,24,25]$. In principle, all of these approaches could be applied, e.g., in a reactive barrier, as long as the factors influencing atrazine dissipation in the subsurface are well enough understood for remediation [26,27].

Accordingly, the aim of this study was to determine whether the formation of atrazine and colloid complexes could be overcome in the above presented sediment slurries $[17,21]$ by bioaugmentation alone or with biostimulation, or by water cycling, which is known to maintain the enhanced mass transfer of herbicides, nutrients and oxygen [5]. Sediments were collected from the groundwater recharge area above the water table at a depth of $13.6 \mathrm{~m}$, through which, for example, contaminated water from a point source pollution flows into groundwater during rainfall or flooding. Short-term atrazine dissipation (10 days) and microbial counts were monitored in the liquid phase of the sediment slurries, modeling stagnant water, and in the circulating water of the sediment columns, modeling the water flow through the sediments. The high atrazine concentration of $100 \mathrm{mg} \mathrm{L}^{-1}$ was used in order to study atrazine degradation above the water solubility limit of about $33 \mathrm{mg} \mathrm{L}^{-1}$ typical in point source pollution, and to study the bioavailability problem limiting microbial degradation when low concentrations are approached. The microbes added in the bioaugmentation were Pseudomonas sp., ADP known to degrade atrazine [28], or four microbes isolated from groundwater monitoring pipe A deposit slurries with microbial atrazine degradation under aerobic conditions [6]. Na-sitrate was added in the biostimulation, as it improves atrazine degradation by Pseudomonas sp. ADP [29]. Aerobic conditions were chosen as nutritionally versatile aerobic microbes dominated in the subsurface aquifer [30,31]. In addition, the most common aerobically growing microbes in the liquid phases were determined by $16 \mathrm{~S}$ rDNA sequencing. The hypotheses of the study were that bioaugmentation alone, 
or with biostimulation or water recycling, will improve atrazine dissipation in aquifer sediments. The null hypothesis was that these factors do not affect atrazine dissipation.

\section{Materials and Methods}

\subsection{Subsurface Deposits and Sediments}

The deposit sampling site for isolating microbial inoculum was located in Lahti, Finland $\left(60^{\circ} 97^{\prime} 24^{\prime \prime} \mathrm{N} / 25^{\circ} 63^{\prime} 21^{\prime \prime} \mathrm{E}\right)$. Gardens, houses, roads and railways are located above the study aquifer [6]. The deposits were collected from the bottom of groundwater monitoring pipe A at $18.5 \mathrm{~m}$ below the soil surface (water table $17.7 \mathrm{~m}$ ) using a Waterra HL 21,507 pump equipped with aggregate Power 2601 BV (2.5 kW, Hollola, Finland). The deposits were accumulated in the pipe through sieves with a pore size of $0.3 \mathrm{~mm}$.

The sediment sampling site for degradation experiments was located next to the railway station in Lahti, Finland. The site is located in a groundwater recharge area, where atrazine has been detected in groundwater and sediments [6,32]. The sediments were collected at the drilling site and directly placed into sterilized plastic bags. The drill diameter was $75 \mathrm{~mm}$ from the topsoil reaching to a depth of approximately $10 \mathrm{~m}$, and $4.8 \mathrm{~cm}$ below this (Destia, Finland). The groundwater table was approximately $15.0 \mathrm{~m}$ below the soil surface, while the study sediments were taken from a depth of ca. $13.6 \mathrm{~m}$, through which contaminated water flows into groundwater.

The dry weight of three parallel samples of 1-3 g was weighed after heating at $105^{\circ} \mathrm{C}$ for $16 \mathrm{~h}$, and then the organic matter content was determined from the weight loss after heating at $550{ }^{\circ} \mathrm{C}$ for $4 \mathrm{~h} \mathrm{[6]}$. To determine total carbon (total-C), three parallel sediment samples of approximately $0.3 \mathrm{~g}$ were weighed and the carbon was determined with a LECO Model 2000 CNS analyzer (St. Joseph, MI, USA) using helium as a carrier gas according to the manufacturer's instructions [33]. To determine $\mathrm{NH}_{4}-\mathrm{N}$ and $\mathrm{NO}_{3}-\mathrm{N}, 1 \mathrm{~h}$ after sediment:water (1:5, weight/volume) extraction the solution was separated by filtration though gauze. The aqueous extract was distilled using boric acid $(0.2 \mathrm{~g})$, bromocresol green $(0.1 \mathrm{~g})$ and methyl red $(0.02 \mathrm{~g})$ as indicators in $100 \mathrm{~mL}$ of methanol. The $\mathrm{HN}_{4}-\mathrm{N}$ was then titrated with $0.5 \mathrm{mM} \mathrm{H}_{2} \mathrm{SO}_{4}$, and the aqueous extract was filtered $(0.45 \mu \mathrm{m})$ to determine nitrate by ion chromatography [34-36]. To analyze the elements $\mathrm{Co}, \mathrm{Cr}, \mathrm{Cu}, \mathrm{Fe}, \mathrm{Mn}, \mathrm{Ni}, \mathrm{Pb}$ and $\mathrm{Zn}, 3 \mathrm{~mL}$ of deionized distilled water, $3 \mathrm{~mL}$ of $37 \% \mathrm{HCl}$ and $1 \mathrm{~mL}$ of nitric acid were added to about $1 \mathrm{~g}$ of insoluble sediment from the dry weight assay. The sample was heated until the material was completely digested, and after filtration, the volume was brought to $50 \mathrm{~mL}$ with deionized distilled water. The sample was analyzed by inductively coupled plasma atomic emission spectrometry using standard reference solutions to determine standard curves for quantification [37,38]. $\mathrm{NH}_{4}-\mathrm{N}, \mathrm{NO}_{3}-\mathrm{N}$ and element analyses were performed as a purchased service at Eurofins Environment Testing Finland Ltd. (Lahti, Finland), which uses methods accredited according to the Finnish Accreditation service T039 (FINAS) [39].

\subsection{Inoculum Preparation}

Four microbial strains were isolated after 176 days' enrichment of the groundwater monitoring pipe A deposit slurry mesocosms, in which microbial atrazine degradation was observed under aerobic conditions [6]. To isolate microbes, $100 \mu \mathrm{L}$ of the liquid was cultivated on mineral agar medium containing $33 \mathrm{mg} \mathrm{L}^{-1}$ of atrazine as a sole nitrogen source [40]. The separate colonies were further re-plated on the same medium until microscopy revealed them to be pure cultures (Olympus SZ40, Hatabaya, Japan). Four isolates from pipe A deposits utilizing atrazine as the sole nitrogen source, and Pseudomonas sp. ADP (DSM 11735, AM088478), were used as inoculants in this study.

For use as an inoculum in the degradation experiments, each microbe was first cultivated for one week at $21 \pm 2{ }^{\circ} \mathrm{C}$ in $10 \mathrm{~mL}$ of mineral medium with $100 \mathrm{mg} \mathrm{L}^{-1}$ of atrazine in four parallel tubes [40]. Then $20 \mathrm{~mL}$ was inoculated to $100 \mathrm{~mL}$ of the same medium, in duplicate, and the suspensions were cultivated for one week in a shaker (150 rpm; Unimax 1010, Heidolph Instruments, Schwabach, Germany). The cells were separated by centrifugation $(4000 \times g, 10 \mathrm{~min}$; Biofuge primo R, Heraeus, 
Hanau, Germany), washed twice with $50 \mathrm{~mL}$ of sterilized distilled water, and finally suspended in $22.5 \mathrm{~mL}$ of sterilized water. The four isolates from the deposits were combined to obtain $90 \mathrm{~mL}$ of suspension. Pseudomonas sp. ADP cells were directly suspended in $90 \mathrm{~mL}$ of sterilized water. The equal volumes of microbial suspensions were added to the bioaugmentation experiments.

\subsection{Degradation Experiments}

In the sediment slurries, sediments ( $15.0 \mathrm{~g}$ dry weight) in $50 \mathrm{~mL}$ of sterilized distilled water were shaken in $100 \mathrm{~mL}$ flasks (150 rpm, Laboshake, Gerhardt, Königswinter, Germany). Atrazine dissipation (the total amount of atrazine, $5 \mathrm{mg} ; 100 \mathrm{mg} \mathrm{L}^{-1}$ of water; $0.333 \mathrm{mg} \mathrm{g}^{-1}$ of sediment) followed in the liquid phase for 10 days in experiments performed in triplicate.

In the sediment columns, $10 \mathrm{~mL}$ sterile syringes were filled with $14.7 \mathrm{~g}$ (dry weight) of sediment, and $160 \mathrm{~mL}$ of liquid was circulated through the sediment column at a flow rate of $16.7 \mathrm{~mL} \mathrm{~min}^{-1}$ using pipes (inner diameter $3 \mathrm{~mm}$ ) connected to a multichannel pump (ISM 404B, Ismatec, Germany). The liquid in the flask was shaken at $150 \mathrm{rpm}$ (Unimax 1010, Heidolph Instruments). Atrazine dissipation (the total amount of atrazine, $16 \mathrm{mg} ; 100 \mathrm{mg} \mathrm{L}^{-1}$ water; $1.067 \mathrm{mg} \mathrm{g}^{-1}$ of sediment) followed in the circulating water for 10 days in experiments performed in duplicate.

Both experiments consisted of eight different treatments as presented in Table 1. The supplements used in the treatments were as follows: Pseudomonas sp. ADP, known to degrade atrazine [29]; the four microbes isolated from groundwater monitoring pipe A deposit slurries, where microbial atrazine degradation was observed under aerobic conditions [6]; atrazine $\left(100 \mathrm{mg} \mathrm{L}^{-1}, 0.5 \mathrm{~mL}\right.$ of stock $10 \mathrm{~g} \mathrm{~L}^{-1}$ in methanol); and Na-citrate $\left(1.0 \mathrm{~g} \mathrm{~L}^{-1}\right)$, known to enhance atrazine degradation by Pseudomonas sp. ADP [29]. The experiments were conducted at a room temperature of $21 \pm 2{ }^{\circ} \mathrm{C}$. The liquid samples of $200 \mu \mathrm{L}$ were taken daily from each flask to follow the rate of atrazine dissipation and microbial counts, and to determine the microbial species growing in the liquid phase.

Table 1. Experimental setup in the sediment slurries and sediment columns.

\begin{tabular}{ccc}
\hline Experiment & Atrazine & Na-citrate \\
\cline { 2 - 3 } & $\mathbf{m g} \cdot \mathbf{L}^{\mathbf{- 1}}$ & $\mathbf{g} \cdot \mathbf{L}^{-\mathbf{1}}$ \\
\hline Control & 0 & 0 \\
Pseudomonas ADP & 0 & 0 \\
Four microbes * & 0 & 0 \\
Atrazine & 100 & 0 \\
Atrazine, Pseudomonas ADP & 100 & 0 \\
Atrazine, Pseudomonas ADP, Na-citrate & 100 & 1.0 \\
Atrazine, four microbes * & 100 & 0 \\
Atrazine, four microbes *, Na-citrate & 100 & 1.0 \\
\hline
\end{tabular}

*ATR16/2, ATR17/2, ATR18/2a, ATR18/2b.

\subsection{Microbial Counts and Identification}

Liquid samples $(100 \mu \mathrm{L})$ from the degradation experiments were diluted ten-fold and cultivated on mineral agar plates [40]. The colonies were counted, and single colonies with different colonial morphologies were further purified by re-plating until they were pure cultures according to microscopy analysis (Olympus SZ40, Hatabaya, Japan).

To characterize the isolates using sequencing, strains were cultivated on mineral agar as presented above. DNA was isolated using the UltraClean ${ }^{\mathrm{TM}}$ Microbial DNA Isolation Kit (MO BIO Laboratories, Carlsbad, CA, USA) according to the instructions. The polymerase chain reaction (PCR) primers for bacterial 16S rDNA detection were $\mathrm{pA}$ and $\mathrm{pH}$ [41], and for fungal internal transcribed spacer (ITS) detection FUN18F and ITS4 (Oligomer, Helsinki, Finland) [42]. Both PCR primers were used under the same conditions. The PCR reactions in a volume of $50 \mu \mathrm{L}$ contained $5 \mu \mathrm{L}$ of $10 \times$ buffer, $0.25 \mathrm{mM}$ of each dNTP, $0.1 \mu \mathrm{M}$ of each primer, approximately $25 \mathrm{ng}$ of template DNA, and $2.0 \mathrm{U}$ of DyNAzyme 
II DNA Polymerase (Thermo Fisher Scientific Inc, MA, USA). DNA was amplified with the DNA Engine DYAD Peltier Thermal Cycler (Bio-Rad, Hercules, CA, USA) using the following program: denaturation for $4 \mathrm{~min}$ at $95^{\circ} \mathrm{C}$; then 30 cycles at $94{ }^{\circ} \mathrm{C}$ for $20 \mathrm{~s}, 50{ }^{\circ} \mathrm{C}$ for $20 \mathrm{~s}$, and $72{ }^{\circ} \mathrm{C}$ for $1 \mathrm{~min}$; and a final extension at $72{ }^{\circ} \mathrm{C}$ for $5 \mathrm{~min}$. The amplification products were analyzed in $1 \%$ agarose gel in a Tris-borate-EDTA buffer ( $\mathrm{pH} 8.0$ ) containing $1.0 \mu \mathrm{g} \mathrm{mL} \mathrm{m}^{-1}$ of ethidium bromide. The DNA bands in gels were visualized by UV transillumination and photographed using a Chemi Imager 5500 (Alpha Innotech Corporation, San Leandron, CA, USA). The partial 16S rRNA genes were sequenced using the universal forward primers $\mathrm{pA}$ or $\mathrm{pB}$, and reverse primers $\mathrm{pD}$ or $\mathrm{pE}$ [43], and fungal ITS genes were sequenced using primers ITS1F and ITS2 [42]. Sequencings in duplicate were performed in the DNA Sequencing Laboratory of the University of Helsinki. The sequences were compiled with the Staden Package (MRC Laboratory of Molecular Biology, 1995-2001, Cambridge, UK) and compared with other $16 \mathrm{~S}$ rDNA sequences in the EMBL database using the FASTA algorithm (January-May, 2015).

\subsection{Pesticide Analyses}

The liquid sample of $100 \mu \mathrm{L}$ was supplemented with $66.1 \mu \mathrm{M}$ simazine as an internal standard, and brought to $600 \mu \mathrm{L}$ with methanol:water $(3: 1 v / v)$. Atrazine standards at five concentrations between 2.3 and $130 \mu \mathrm{M}$ in methanol:water $(3: 1 v / v)$ had $66.1 \mu \mathrm{M}$ simazine as an internal standard. The standard curves were linear with the correlation coefficients $(r \pm$ standard deviation) of $0.995 \pm 0.004$. The limit of detection (LOD) varied between 2.0 and $2.6 \mu \mathrm{M}$. The liquid samples and standards were filtered through $0.45 \mu \mathrm{m}$ GHP membranes (Acrodisc, Gelman, Pall Corporation Ltd., NY, USA), and $20 \mu \mathrm{L}$ was analyzed using an HPLC: Shimadzu Prominence (Shimadzu, Kyoto, Japan), SIL-20A autosampler, LC-20AT solvent delivery module, DGU-20A5 on-line degasser, SPD-20A UV/VIS detector (225 nm), LC Solution software and SunFire column $\left(0.6 \mathrm{~mL} \mathrm{~min}^{-1}\right.$; C18, $3.5 \mu \mathrm{m}, 3.0 \times 150 \mathrm{~mm}$, Waters, MA, USA), as presented earlier [44]. The initial acetonitrile concentration in filtered water was $30 \%$ for $2.5 \mathrm{~min}$, which was increased to $65 \%$ for $5 \mathrm{~min}$, and finally back to $30 \%$ for $3.5 \mathrm{~min}$.

To define the quantity of atrazine retained in the sediments by the end of the experiment, $150 \mathrm{mg}$ of sediment (wet weight) from each column was extracted in $1.5 \mathrm{~mL}$ of methanol:water $(3: 1, v / v)$. Propazine (321 nmol) was added as an internal standard. The sample was mixed carefully, sonicated $(40 \mathrm{kHz}$, Everest, Istanbul, Turkey) for $15 \mathrm{~min}$ at $20^{\circ} \mathrm{C}$, and then shaken (200 rpm, Unimax 1010, Heidolph Instruments) overnight at $21 \pm 2{ }^{\circ} \mathrm{C}$. After centrifugation for $10 \mathrm{~min}$ at $1250 \times \mathrm{g}$ (Biofuge primo $\mathrm{R}$, Heraeus), the extract was separated, and stored at $-20{ }^{\circ} \mathrm{C}$. The extraction was repeated three times, after which the extracts were combined, and $20 \mu \mathrm{L}$ was analyzed by HPLC as presented above. The LOD for atrazine was approximately $100 \mathrm{nmol} \mathrm{g}^{-1}$ of sediment, and the extraction recovery was about $90 \%$. The same standard concentrations as above formed a standard curve with $r$ value of 0.963 .

To decrease the LOD to ca. $1.7 \mathrm{nmol} \mathrm{g}^{-1}$ for atrazine, DEA, DIA and DEDIA, all column sediments were extracted using the method presented earlier [32], which in essential parts followed that described above. The extraction recovery was about $68 \%$, based on internal standard. The sediment dry weight was $14.7 \mathrm{~g}$ in the extractions, $87.1 \mathrm{nmol}$ of propazine was added as an internal standard, and $18 \mathrm{~mL}$ of methanol:water $(3: 1, v / v)$ was used in the extractions. The methanol:water $(3: 1 v / v)$ of the combined extracts was evaporated under a nitrogen flow, and the precipitate was extracted twice with $300 \mu \mathrm{L}$ of acetone using sonication (15 min, $43 \mathrm{kHz} / 320 \mathrm{~W}$, Branson 8510 Ultrasonic Cleaner, W.A. Brown Industrial Sales Inc, Richmond, VA, USA), followed by centrifugation $(13000 \times g)$. The pooled acetone fractions were filtered and pesticides were analyzed by Shimadzu GCMS-QP-2010 Ultra gas chromatograph mass spectrometer, autosampler AOC-20i+s, and ZB-5MS capillary column (29 m, $0.25 \mathrm{~mm}, 0.25 \mu \mathrm{m})$. Helium was the carrier gas $\left(1.29 \mathrm{~mL} \mathrm{~min}^{-1}\right)$, the injector temperature was $250{ }^{\circ} \mathrm{C}$, and injection $(2 \mu \mathrm{L})$ was splitless. The oven temperature was programmed to hold $120^{\circ} \mathrm{C}$ for $2 \mathrm{~min}$, and then increase $20^{\circ} \mathrm{C} \mathrm{min}-1$ to $180{ }^{\circ} \mathrm{C}$, hold for $5 \mathrm{~min}$, and then $20^{\circ} \mathrm{C} \mathrm{min}^{-1}$ to $280{ }^{\circ} \mathrm{C}$, hold for $8 \mathrm{~min}$. The mass spectra were recorded at electron energy of $70 \mathrm{eV}$. The ion source temperature was $230{ }^{\circ} \mathrm{C}$, and that of the interface was $250{ }^{\circ} \mathrm{C}$. Five standards in methanol:water $(3: 1, v / v)$ contained 
atrazine, DEA, DIA, and DEDIA of 0.13-3.44 $\mathrm{nmol} \mathrm{L}^{-1}$. The $\mathrm{r}$ value of the standard curve was 0.999 . The ions that followed were $\mathrm{m} / \mathrm{z} 202$ and 215 (quantification) for atrazine, 174 (quantification) and 187 for DEA, m/z 158 (quantification), 173 and 175 for DIA, m/z 110, 145 (quantification) and 147 for DEDIA, and $\mathrm{m} / \mathrm{z} 172,187,214$ and 229 (quantification) for propazine.

\subsection{Calculations}

The nonparametric, two-factor Kruskal-Wallis test $(\mathrm{K}-\mathrm{W})$ was used to determine whether atrazine dissipation and microbial numbers could be related to the system mode (stagnant/flowing water) and treatments (Table 1), as the Levene's test of equality of variances was significant. The pesticide concentrations ( $\mathrm{mg} \mathrm{L}^{-1}$ of water, and $\mathrm{mg} \mathrm{g}^{-1}$ of sediment) and microbial numbers of the last five sampling days under stabilized conditions were used in the statistical analyses $(n=5)$. The pairwise comparisons between treatments were performed using Mann-Whitney's test (M-W). K-W and M-W were performed using PASW Statistics 18, Release 18.0.0 for Windows (SPSS Inc., Chicago, IL, USA).

\section{Results}

Atrazine dissipation and associated microbial growth were monitored for 10 days in the liquid phase of stagnant sediment slurries, and in the water circulating in sediment columns. In addition to (1) control sediments (no additives), the following amendments were included in the study arrangements: (2) Pseudomonas sp. ADP; (3) four microbes; (4) atrazine; (5) atrazine and Pseudomonas sp. ADP; (6) atrazine, Pseudomonas sp. ADP and Na-citrate; (7) atrazine and four microbes; (8) atrazine, four microbes and Na-citrate (Table 1). The four inoculum isolates from the subsurface deposits were identified as bacteria from genera Pseudomonas (ATR18/2) and Janthinobacterium (ATR17/2), and fungi from genera Acremonium (ATR16/2) and Penicillium (ATR18/2b) (Table 2). The percentage of organic matter in the sediments was only $0.4 \%$, Fe and Mn were the most common elements, and other elements were present in low quantities of $3-27 \mu g g^{-1}$ of sediment (Table 3). $\mathrm{NH}_{4}-\mathrm{N}$ and $\mathrm{NO}_{3}-\mathrm{N}$ were below the detection limit.

According to the two-factor Kruskal-Wallis test $(p<0.01)$, the system mode (stagnant/flowing water) and treatments had significant effects on both atrazine dissipation and microbial growth (Table 4). The atrazine concentrations and microbial numbers in the water circulating in the sediment columns were significantly lower than in the liquid phase of the sediment slurries (M-W, $p \leq 0.003$ ), while bioaugmentation and biostimulation with Na-citrate did not significantly affect atrazine concentrations. 
Table 2. Isolated microbes; bacterial identification by partial $16 \mathrm{~S}$ rDNA sequencing at nucleotide positions presented (Escherichia coli numbering [45]), and fungal sequence numbering based on the nearest neighbor sequences; sequence accession numbers ( $\mathrm{ACNO}$ ); similarity percentages to the nearest neighbors, and their isolation sources and ACNOs.

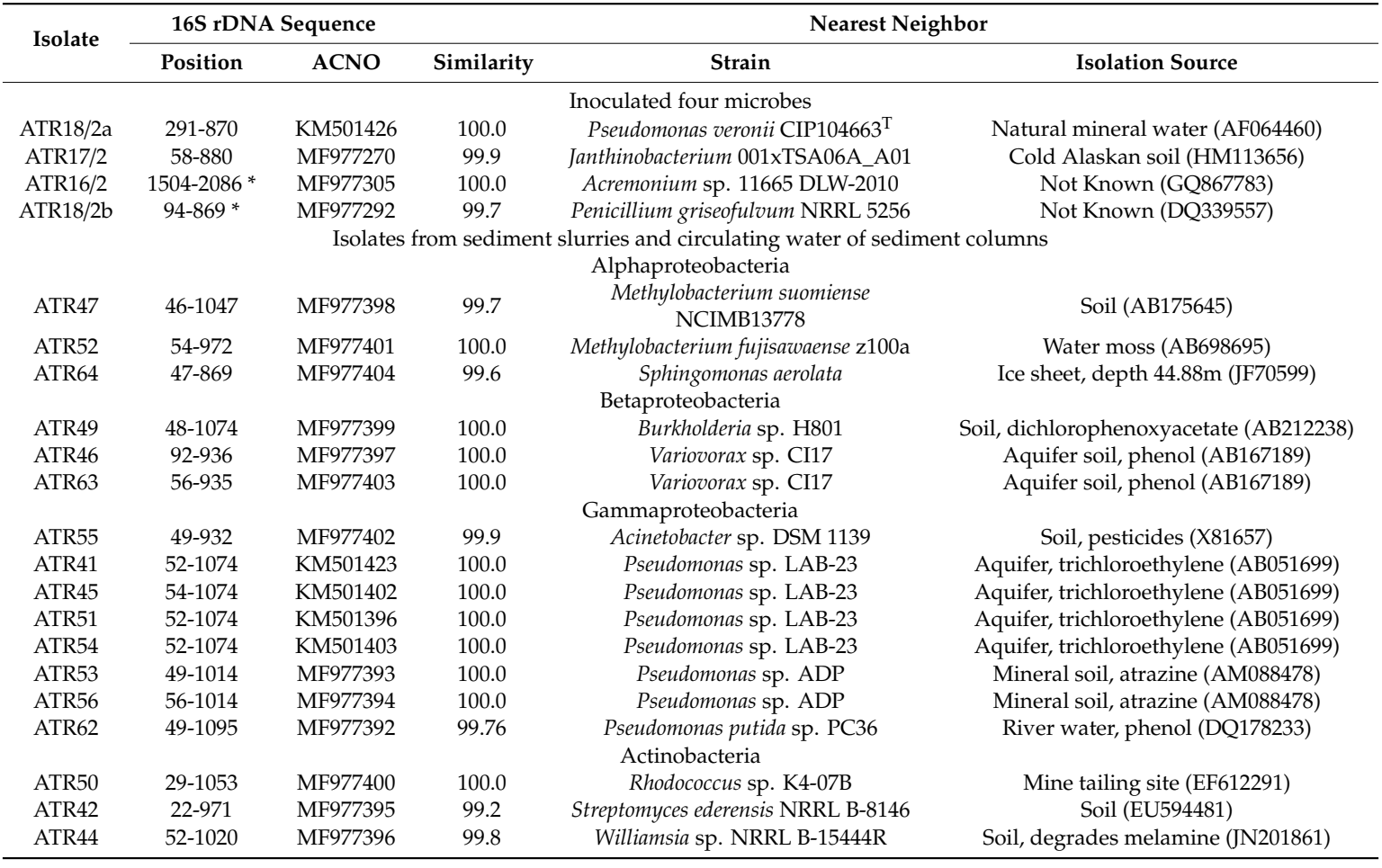

Table 3. Chemical composition of sediments on a dry weight basis.

\begin{tabular}{cc}
\hline Compound & Concentration \\
\hline Organic matter $\left(\mathrm{mg} \cdot \mathrm{g}^{-1}\right)$ & $4.3 \pm 0.2$ \\
Total carbon $\left(\mathrm{mg} \cdot \mathrm{g}^{-1}\right)$ & $0.3 \pm 0.1$ \\
$\mathrm{NH}_{4}-\mathrm{N}\left(\mu \mathrm{g} \cdot \mathrm{g}^{-1}\right)$ & $<0.39 *$ \\
$\mathrm{NO}_{3}-\mathrm{N}\left(\mu \mathrm{g} \cdot \mathrm{g}^{-1}\right)$ & $<0.1^{*}$ \\
$\mathrm{Co}\left(\mu \mathrm{g} \cdot \mathrm{g}^{-1}\right)$ & $3 \pm 1$ \\
$\mathrm{Cr}\left(\mu \mathrm{g} \cdot \mathrm{g}^{-1}\right)$ & $12 \pm 4$ \\
$\mathrm{Cu}\left(\mu \mathrm{g} \cdot \mathrm{g}^{-1}\right)$ & $15 \pm 5$ \\
$\mathrm{Fe}\left(\mathrm{mg} \cdot \mathrm{g}^{-1}\right)$ & $12 \pm 3$ \\
$\mathrm{Mn}\left(\mu \mathrm{g} \cdot \mathrm{g}^{-1}\right)$ & $96 \pm 24$ \\
$\mathrm{Ni}\left(\mu \mathrm{g} \cdot \mathrm{g}^{-1}\right)$ & $6 \pm 2$ \\
$\mathrm{~Pb}\left(\mu \mathrm{g} \cdot \mathrm{g}^{-1}\right)$ & $3 \pm 1$ \\
$\mathrm{Zn}\left(\mu \mathrm{g} \cdot \mathrm{g}^{-1}\right)$ & $27 \pm 9$ \\
\hline
\end{tabular}

${ }^{*}$ below the detection limit. 
Table 4. Microbial numbers and atrazine concentrations in degradation experiments using stagnant sediment slurries and circulating water in sediment columns.

\begin{tabular}{|c|c|c|c|c|c|c|c|c|}
\hline \multirow{3}{*}{$\begin{array}{l}\text { Treatment } \\
\text { Treatment }\end{array}$} & \multicolumn{4}{|c|}{ Atrazine (Stabilized, day 10) } & \multicolumn{4}{|c|}{ Microbial Numbers } \\
\hline & \multicolumn{2}{|c|}{$\mathrm{mg} \mathrm{L}^{-1}$ of Liquid } & \multicolumn{2}{|c|}{$\mathrm{mg} \mathrm{g}^{-1}$ of Sediment } & \multicolumn{2}{|c|}{ Initial (Day 0) } & \multicolumn{2}{|c|}{ Stabilized (Day 10) } \\
\hline & A & B & A & B & A & B & A & B \\
\hline a.Control & $<0.5^{\mathrm{d}, \mathrm{e}, \mathrm{f}, \mathrm{g}, \mathrm{h}, \mathrm{B}, *}$ & $<0.5^{\mathrm{d}, \mathrm{e}, \mathrm{f}, \mathrm{g}, \mathrm{h}, \mathrm{A}, *}$ & $<0.002^{\mathrm{d}, \mathrm{e}, \mathrm{f}, \mathrm{g}, \mathrm{h}, \mathrm{B}, *}$ & $<0.005^{\mathrm{d}, \mathrm{e}, \mathrm{f}, \mathrm{g}, \mathrm{h}, \mathrm{A}, *}$ & $1.0 \times 10^{3}$ & $1.0 \times 10^{1}$ & $6.7 \times 10^{4 d, e, f, g, h, B}$ & $1.0 \times 10^{2 c, b, d, f, g, h, h}$ \\
\hline b.Pseudomonas ADP & $0.8 \pm 0.7^{\mathrm{d}, \mathrm{e}, \mathrm{f}, \mathrm{g}, \mathrm{h}, \mathrm{h}, \mathrm{B}}$ & $<0.5^{\mathrm{d}, \mathrm{e}, \mathrm{f}, \mathrm{g}, \mathrm{h}, \mathrm{A}, *}$ & $0.003 \pm 0.002^{\mathrm{d}, \mathrm{e}, \mathrm{f}, \mathrm{g}, \mathrm{g}, \mathrm{h}, \mathrm{B}}$ & $<0.005^{\mathrm{d}, \mathrm{e}, \mathrm{f}, \mathrm{g}, \mathrm{h}, \mathrm{A}, *}$ & $1.0 \times 10^{3}$ & $1.0 \times 10^{2}$ & $8.2 \times 10^{3 \mathrm{~d}, \mathrm{e}, \mathrm{f}, \mathrm{g}, \mathrm{h}, \mathrm{B}}$ & $2.8 \times 10^{3 \mathrm{a}, \mathrm{d}, \mathrm{f}, \mathrm{g}, \mathrm{A}}$ \\
\hline c.Four microbes & $1.9 \pm 0.7^{\mathrm{d}, \mathrm{e}, \mathrm{f}, \mathrm{g}, \mathrm{h}, \mathrm{B}}$ & $<0.5^{\mathrm{d}, \mathrm{e}, \mathrm{f}, \mathrm{g}, \mathrm{h}, \mathrm{A}, *}$ & $0.006 \pm 0.002^{\mathrm{d}, e, \mathrm{e}, \mathrm{g}, \mathrm{g}, \mathrm{h}, \mathrm{B}}$ & $<0.005^{\mathrm{d}, \mathrm{e}, \mathrm{f}, \mathrm{g}, \mathrm{h}, \mathrm{A}, *}$ & $1.0 \times 10^{3}$ & $1.0 \times 10^{1}$ & $8.0 \times 10^{4 \mathrm{~d}, \mathrm{e}, \mathrm{f}, \mathrm{g}, \mathrm{h}, \mathrm{B}}$ & $1.0 \times 10^{3 \mathrm{a}, \mathrm{d}, \mathrm{f}, \mathrm{g}, \mathrm{A}}$ \\
\hline d.Atrazine & $61.9 \pm 8.9^{\mathrm{a}, \mathrm{b}, \mathrm{c}, \mathrm{B}}$ & $10.3 \pm 2.0^{\mathrm{a}, \mathrm{b}, \mathrm{c}, \mathrm{A}}$ & $0.206 \pm 0.030^{\mathrm{a}, \mathrm{b}, \mathrm{c}, \mathrm{B}}$ & $0.112 \pm 0.022^{\mathrm{a}, \mathrm{b}, \mathrm{c}, \mathrm{A}}$ & $1.0 \times 10^{3}$ & $1.0 \times 10^{1}$ & $>10^{8 \mathrm{a}, \mathrm{b}, \mathrm{c}, \mathrm{B}}$ & $5.5 \times 10^{3 \mathrm{a}, \mathrm{b}, \mathrm{c}, \mathrm{f}, \mathrm{A}}$ \\
\hline e.Atrazine,Pseudomonas ADP & $56.4 \pm 5.8^{\mathrm{a}, \mathrm{b}, \mathrm{c}, \mathrm{B}}$ & $11.8 \pm 1.3^{\mathrm{a}, \mathrm{b}, \mathrm{c}, \mathrm{A}}$ & $0.188 \pm 0.019^{\mathrm{a}, \mathrm{b}, \mathrm{c}, \mathrm{B}}$ & $0.129 \pm 0.014^{\mathrm{a}, \mathrm{b}, \mathrm{c}, \mathrm{A}}$ & $1.0 \times 10^{3}$ & $1.0 \times 10^{2}$ & $>10^{8 \mathrm{a}, \mathrm{b}, \mathrm{c}, \mathrm{B}}$ & $2.4 \times 10^{3 \mathrm{f}, \mathrm{g}, \mathrm{A}}$ \\
\hline $\begin{array}{c}\text { f.Atrazine,Pseudomonas } \\
\text { ADP,Na-citrate }\end{array}$ & $63.8 \pm 4.3^{\mathrm{a}, \mathrm{b}, \mathrm{c}, \mathrm{B}}$ & $10.3 \pm 3.5^{\mathrm{a}, \mathrm{b}, \mathrm{c}, \mathrm{A}}$ & $0.213 \pm 0.014^{\mathrm{a}, \mathrm{b}, \mathrm{c}, \mathrm{B}}$ & $0.112 \pm 0.038^{\mathrm{a}, \mathrm{b}, \mathrm{c}, \mathrm{A}}$ & $1.0 \times 10^{3}$ & $1.0 \times 10^{2}$ & $>10^{8 \mathrm{a}, \mathrm{b}, \mathrm{c}, \mathrm{B}}$ & $4.6 \times 10^{4 a, b, c, d, e, h, A}$ \\
\hline e.Atrazine,four microbes & $53.4 \pm 3.7^{\mathrm{a}, \mathrm{b}, \mathrm{c}, \mathrm{B}}$ & $15.8 \pm 1.2^{\mathrm{a}, \mathrm{b}, \mathrm{c}, \mathrm{A}}$ & $0.178 \pm 0.012^{\mathrm{a}, \mathrm{b}, \mathrm{c}, \mathrm{B}}$ & $0.172 \pm 0.013^{\mathrm{a}, \mathrm{b}, \mathrm{c}, \mathrm{A}}$ & $1.0 \times 10^{3}$ & $1.0 \times 10^{2}$ & $>10^{8 \mathrm{a}, \mathrm{b}, \mathrm{c}, \mathrm{B}}$ & $8.0 \times 10^{4 a, b, c, e, h, A}$ \\
\hline $\begin{array}{c}\text { h.Atrazine,four } \\
\text { microbes,Na-citrate }\end{array}$ & $61.1 \pm 6.1^{\mathrm{a}, \mathrm{b}, \mathrm{c}, \mathrm{B}}$ & $17.5 \pm 2.1^{\mathrm{a}, \mathrm{b}, \mathrm{c}, \mathrm{A}}$ & $0.204 \pm 0.020^{\mathrm{a}, \mathrm{b}, \mathrm{c}, \mathrm{B}}$ & $0.190 \pm 0.023^{\mathrm{a}, \mathrm{b}, \mathrm{c}, \mathrm{A}}$ & $1.0 \times 10^{3}$ & $1.0 \times 10^{2}$ & $>10^{8 \mathrm{a}, \mathrm{b}, \mathrm{c}, \mathrm{B}}$ & $2.6 \times 10^{3 \mathrm{a}, \mathrm{f}, \mathrm{g}, \mathrm{A}}$ \\
\hline
\end{tabular}

The superscript letters a-h indicates statistically significant differences in microbial numbers or atrazine concentrations between treatments. Stagnant sediment slurries (A); Circulating water in sediment columns (B); Below the detection limit $\left(^{*}\right)$. 


\subsection{Atrazine Degradation in the Sediment Slurries}

The cell numbers increased over a couple of days from ca. $1.0 \times 10^{3} \mathrm{cfu} \mathrm{mL}^{-1}$ to nearly equivalent levels of $0.82-8.0 \times 10^{4} \mathrm{cfu} \mathrm{mL}^{-1}$ in the liquid phase of the controls and slurries amended with microorganisms (Pseudomonas sp. ADP, four microbes), but not with atrazine (Table 4). Instead, the cell numbers in the liquid phase of the atrazine-amended slurries $\left(100 \mathrm{mg} \mathrm{L}^{-1}\right)$ increased to $\geq 10^{8} \mathrm{cfu} \mathrm{mL} \mathrm{m}^{-1}$ in a few days, and the atrazine concentration simultaneously decreased to $53-64 \mathrm{mg} \mathrm{L}^{-1}$ (0.178- $-0.213 \mathrm{mg} \mathrm{g}^{-1}$ of sediment) (Figure 1; Table 4). The addition of Pseudomonas sp. ADP, four microbes or Na-citrate had minor effects on the atrazine concentrations and cell numbers. The low atrazine concentrations $\left(0.8-1.9 \mathrm{mg} \mathrm{L}^{-1}\right)$ detected in the liquid phases of the slurries amended with Pseudomonas sp. ADP or four microbes were residues inoculated with microorganisms (Table 4). At the end of the experiment, the quantity of atrazine extracted from the atrazine-amended slurry sediments was $129.3 \pm 43.9 \mu \mathrm{g}$, which is equivalent to $2.6 \pm 0.9 \mu \mathrm{g} \mathrm{L}{ }^{-1}$ of liquid and $8.6 \pm 2.9 \mu \mathrm{g} \mathrm{g}^{-1} \mathrm{of}$ sediment. DEA, DIA and DEDIA were not detected in the extracts.

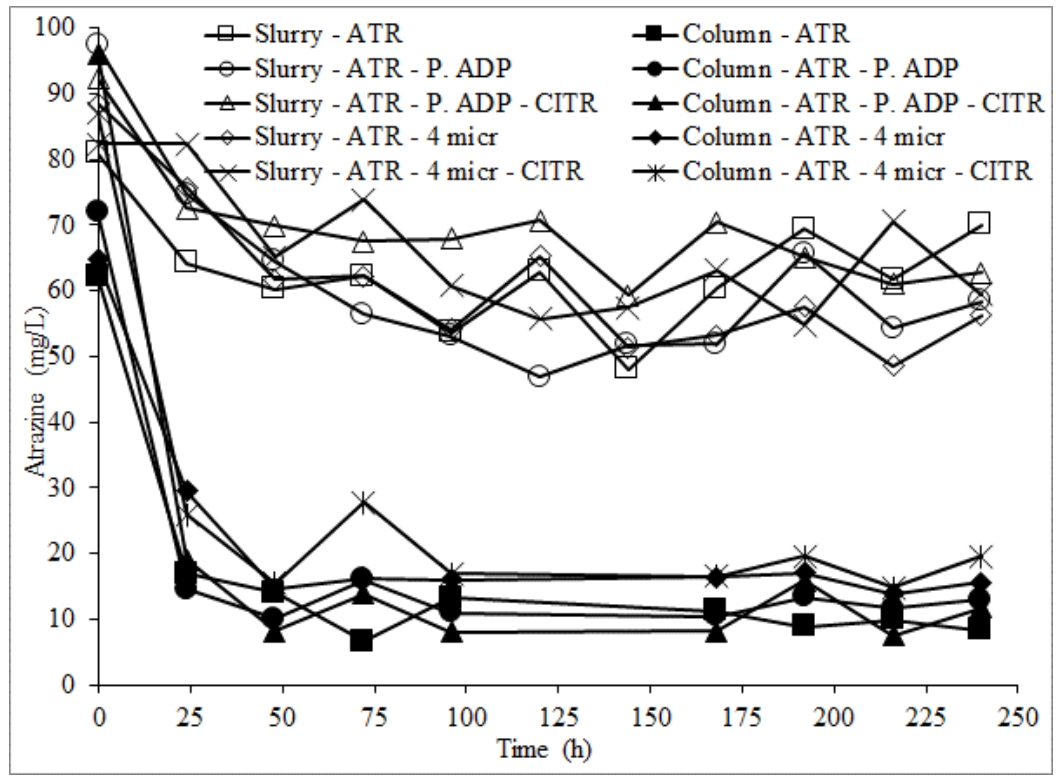

Figure 1. Atrazine dissipation in treatments over ten days. The initial atrazine concentration was $100 \mathrm{mg} / \mathrm{L}$. Slurries and the water circulating in sediment columns were supplemented with atrazine (ATR), Pseudomonas sp. ADP (P. ADP), 4 microbes (4 micr) growing on atrazine as a nitrogen source, and/or Na-citrate (CITR). Atrazine concentrations between the slurry and column experiments differed significantly based on Kruskal-Wallis test $(p<0.01)$ followed by Mann-Whitney's test $(p \leq 0.003)$.

\subsection{Atrazine Degradation in the Circulating Water of the Sediment Columns}

The microbial numbers were low in the circulating water of the sediment columns-between $1.0 \times 10^{1}$ and $1.0 \times 10^{2} \mathrm{cfu} \mathrm{\textrm {mL } ^ { - 1 }}$ at the beginning of the experiment (Table 4 ). The numbers slightly increased in a few days, to $0.1-2.8 \times 10^{3} \mathrm{cfu} \mathrm{mL}^{-1}$ in the circulating water of the columns without atrazine, and were equal to or lower than the microbial numbers of $0.24-8.0 \times 10^{4} \mathrm{cfu} \mathrm{mL}^{-1}$ in the treatments with atrazine. The highest microbial numbers were measured in the circulating water of the columns inoculated with atrazine, with atrazine, Pseudomonas sp. ADP and Na-citrate, or with atrazine and the four microbes, though differences in microbial numbers were generally small.

The concentration of added atrazine decreased remarkably to $10-18 \mathrm{mg} \mathrm{L}^{-1}\left(0.112-0.190 \mathrm{mg} \mathrm{g}^{-1}\right.$ of sediment) in the circulating water of the columns (Table 4, Figure 1). The atrazine concentrations were equal in the circulating water of the columns amended with atrazine, atrazine and Pseudomonas sp. ADP, atrazine, Pseudomonas sp. ADP and Na-citrate, atrazine and the four microbes, or atrazine, the four microbes and Na-citrate. At the end of the experiment, the quantity of atrazine extracted from the 
atrazine-amended column sediments was $50.1 \pm 25.8 \mu \mathrm{g}$, which is equivalent to $312.8 \pm 161.4 \mu \mathrm{g} \mathrm{L}^{-1}$ of liquid and $3.4 \pm 1.8 \mu \mathrm{g} \mathrm{g}^{-1}$ of sediment. DEA, DIA and DEDIA were not detected.

\subsection{Cultivated Bacteria}

Three Gram-positive actinobacteria from genera Rhodococcus (ATR50), Streptomyces (ATR42) and Williamsia (ATR44) were isolated from the liquid phases of sediment slurries and from the circulating waters of sediment columns on mineral agar containing atrazine as a sole nitrogen source (Table 2). The rest of the isolates were from the phylum proteobacteria. The isolates from class alphaproteobacteria belonged to genera Methylobacterium (ATR47, ATR52) and Sphingomonas (ATR64). The isolates from class betaproteobacteria belonged to genera Burkholderia (ATR49) and Variovorax (ATR46, ATR63), and the isolates from class gammaproteobacteria belonged to genera Acinetobacter (ATR55) and Pseudomonas (ATR41, ATR45, ATR51, ATR53, ATR54, ATR56, ATR62). The inoculated two bacteria (ATR18/2, ATR17/2) and two fungi (ATR16/2, ATR18/2b) did not grow among the major cultivable microbes in the experiments, i.e., they may have been overgrown by the isolates from the liquid phase of the slurries and from the circulating water of the sediment columns. Pseudomonas isolates ATR53 and ATR56 had the same $16 \mathrm{~S}$ rDNA sequence as Pseudomonas sp. ADP.

\section{Discussion}

\subsection{Atrazine Dissipation in the Sediment-Water Systems}

Atrazine dissipated rapidly down to $53-64 \mathrm{mg} \mathrm{L}^{-1}$ in the liquid phases of the sediment slurries, and further to $10-18 \mathrm{mg} \mathrm{L}^{-1}$ in the circulating water of the sediment columns, regardless of the additives, and thereafter, no dissipation occurred (Table 4, Figure 1). The stabilized atrazine concentrations in the liquid phases of the sediment slurries were above the $33 \mathrm{mg} \mathrm{L}^{-1}$ water solubility limit [46], whereas the concentration was below the water solubility limit in the circulating water of the sediment columns. However, sediment particles affect atrazine solubility, and the actual solubility is not known. For comparison, atrazine was persistent in the liquid phase of subsurface deposit slurries, with half-lives of hundreds of days to no dissipation in the presence of an initial atrazine concentration of $30 \mathrm{mg} \mathrm{L}^{-1}$ [6], which is below the concentration limit for dissipation of 53-64 mg L $\mathrm{m}^{-1}$ observed in this study. Thus, atrazine can also dissipate rapidly in the presence of an initial concentration of $100 \mathrm{mg} \mathrm{L}^{-1}$, but the dissipation ceased while the atrazine concentration was still quite high.

The concentration limits for the slow dissipation of other compounds are often lower than that for atrazine; for example, dichlobenil and its degradation product 2,6-dichlorobenzamide (BAM) initially dissipated rapidly in the liquid phase of deposit slurries down to the low concentrations of 1.0-6.3 and 3.0-11.3 $\mathrm{mg} \mathrm{L}^{-1}$, respectively [44]. This could be due to the chemical properties of atrazine. It is more water soluble than dichlobenil, and less water-soluble than BAM (atrazine, $33 \mathrm{mg} \mathrm{L}^{-1}$; dichlobenil $14.6 \mathrm{mg} \mathrm{L}^{-1}$ [46]; BAM, $2.7 \mathrm{~g} \mathrm{~L}^{-1}$ [47]). Dichlobenil evaporates more easily than atrazine or BAM (Henry's constant: dichlobenil, $1.02 \mathrm{~Pa} \mathrm{~m}^{3} \mathrm{~mol}^{-1}$; atrazine, $1.5 \times 10^{-4} \mathrm{~Pa} \mathrm{~m}^{3} \mathrm{~mol}^{-1}$ [46]; BAM, $1.242 \times 10^{-4} \mathrm{~Pa} \mathrm{~m}^{3} \mathrm{~mol}^{-1}$ [48]). Further, dichlobenil has a higher capacity than atrazine for sorption (sorption distribution coefficient: dichlobenil, $\mathrm{K}_{\mathrm{d}}, 2.6-126.01 \mathrm{~L} \mathrm{~kg}^{-1}$; atrazine, $0.2-18 \mathrm{~L} \mathrm{~kg}^{-1}$; [46]) and organic carbon binding (organic carbon partition coefficient $\mathrm{K}_{\mathrm{oc}}$ : dichlobenil 500-896 $\mathrm{mL} \mathrm{g}^{-1}$ [48]; atrazine, 39-173 $\mathrm{mL} \mathrm{g}^{-1}$ [46]), both of which could lead to rapid adsorption-catalyzed dissipation [5,49]. As a result, dichlobenil either evaporates or dissipates easily. Compared to BAM ( $\mathrm{K}_{\mathrm{d}}: 0.10-0.93 \mathrm{~L} \mathrm{~kg}^{-1}$ [46]; $\mathrm{K}_{\mathrm{OC}}$ : 33-35 $\mathrm{mL} \mathrm{g}^{-1}$ [48]), atrazine has a higher capacity for sorption and organic carbon sequestration, leading to atrazine dissipation in the presence of high levels of organic matter, but not in groundwater conditions [17]. Moreover, atrazine in the water solution forms complexes with colloids and metal ions, such as $\mathrm{Mn}, \mathrm{Mg}, \mathrm{Ca}, \mathrm{Cd}, \mathrm{Pb}$ or $\mathrm{Zn}$ [22,23,50-52]. For example, $\mathrm{Mn}$ and $\mathrm{Zn}$ were present in the sediments of this study (Table 3), and $\mathrm{Mn}^{2+}$ ions are commonly found in groundwater in Finland [53]. Such interactions could prevent the bioavailability 
of atrazine for microbial degradation in the water phases of subsurface sediments, although degrading microorganisms are present.

Mechanical forces in water pumping through sediment columns can cause physicochemical transformations and the enhanced mass transfer of atrazine, nutrients and oxygen [5,50]. They can release atrazine, which is adsorbed on sediments and forms complexes with ions and colloids in the water phase, increasing bioavailability and microbial degradation (Table 4). In this study, the quantities of colloids and metal ions added with the sediments were equal in both sediment-water systems. The initial atrazine quantity $\left(100 \mathrm{mg} \mathrm{L}^{-1}\right)$ in the circulating water of the sediment columns $(16 \mathrm{mg})$ was much higher than in the slurries ( $5 \mathrm{mg}$ ), as more water was needed to fill the column, pipelines and shaker flask. Still, in the end of the experiments, the atrazine concertation per gram of sediment in the water of slurries was significantly higher than in the circulating water of the sediment columns (Table 4), indicating that water circulation enhanced atrazine dissipation. In comparison, rhamnolipid, Triton X-100 and cyclodextrin surfactants [17,52] did not improve the microbial atrazine degradation as much as forces caused by water flow in the sediment columns.

\subsection{Microbial Growth in the Sediment-Water Systems}

Adsorption to sediments does not explain the initial rapid removal of atrazine from the water phase, as the quantities adsorbed to the slurry and columns sediments were only ca. 129.3 and $50.1 \mu \mathrm{g}$, respectively. The rapid increase in microbial numbers in the liquid phase of the atrazine-added sediment slurries, but not in the treatments without atrazine, indicates that some of the atrazine was degraded as a microbial growth substrate (Table 4). The subsurface sediments contaminated with about $13 \mu \mathrm{g} \mathrm{kg}^{-1}$ of atrazine [32] appeared to inherently contain microbes that are able to rapidly degrade atrazine, which is often disputed due to the absence of microbial pesticide degradation at concentrations below the water solubility limit of $33 \mathrm{mg} \mathrm{L}^{-1}[6,21,54]$.

At the beginning of the experiment, microbial numbers were as low as $0.1-1.0 \times 10^{2} \mathrm{cfu} \mathrm{mL}^{-1}$ in the circulating water of the sediment columns, and $1.0 \times 10^{3} \mathrm{cfu} / \mathrm{mL}$ in the liquid phase of the sediment slurry (Table 4), though $3.3 \times 10^{7}$ cells $\mathrm{g}^{-1}$ dry sediment were measured using phospholipid fatty acid analysis [32]. This indicated the poor cultivability and low microbial activity of subsurface sediments, where aerobic and nutritionally versatile microorganisms have dominated $[31,55]$. The microbial numbers in the circulating water of the sediment columns were lower than in the liquid phase of the sediment slurries throughout the study, possibly because some of the microbes were bound to the sediment columns during the water circulation. The cultivable microbial numbers in the liquid phase of the sediment slurries increased to $>10^{8} \mathrm{cfu} \mathrm{mL}^{-1}$, while atrazine was degraded under aerobic conditions (Table 4). In surface soils treated with $\geq 100 \mathrm{mg} \mathrm{kg}^{-1}$ of atrazine, increased microbial growth and activity were associated with decreased diversity compared to soils treated with $\leq 10 \mathrm{mg} \mathrm{kg}^{-1}$ of atrazine [56]. Similarly, in this study, increased microbial growth and activity were associated with low diversity, as cultivated strains with different colony morphologies belonged to only nine genera (Table 2).

In total, 14 isolates cultivable on mineral agar medium with atrazine as the sole nitrogen source belonged to the phylum proteobacteria, and three to the actinobacteria (Table 2). Both phyla are typical for subsurface sediments $[31,54]$. The nearest neighbor strains of the isolates from the sediment-water systems grew in soil (soil, aquifer soil, mineral soil), water-related environments (ice, river water, water moss) or in the presence of contaminants 2,4-dichlorophenoxyacetic acid, phenol, trichloroethylene, mine tailing, melamine or pesticides (organophosphate or carbamate pesticides) (Table 2). Members from all isolated genera have been associated with atrazine degradation [40,52,57-59], and they could be important in the aerobic remediation of atrazine from subsurface sediments, e.g., in situ aeration $[60,61]$. However, atrazine was not degraded during the 10-day experiments below the concentrations of 53-64 mg L $\mathrm{m}^{-1}$ and $10-18 \mathrm{mg} \mathrm{L}^{-1}$ in the liquid phase of the sediment slurries and in the circulating water of the sediment columns, respectively (Table 4, Figure 1). 
The four added microbes did not affect atrazine degradation, and they did not grow among the major cultivable microbial population (Tables 2 and 4). The microbes were isolated from the mesocosms of the groundwater monitoring pipe A deposits, where microbes degraded atrazine under aerobic conditions [6]. Pseudomonas sp. ATR18/2 belongs to Pseudomonas veronii-like strains, which have grown in a wide range of different environments, including groundwater $[40,62]$. The nearest neighbor strains of Janthinobacterium sp. ATR17/2 have been isolated from cold Alaskan soil [63], low temperature sewage (JX515338) and the Bogota River (EF111135), i.e., from soil and water under low temperature conditions. The isolation sources for the nearest neighbor strains of fungi Acremonium sp. ATR16/2 and Penicillium sp. ATR18/2b are not known [64]. Fungi were detected in the sediment slurries more frequently than in the circulating water of the sediment columns, while cultivable fungi were less represented than bacteria in almost all samples.

Pseudomonas sp. ADP-like strains ATR53 and ATR56 grew in the sediment-water systems among the major microbial population, however atrazine was not degraded below 10-64 mg L $\mathrm{L}^{-1}$ during the 10-day experiment (Tables 2 and 4). Na-citrate did not affect atrazine degradation, although it enhanced atrazine degradation by the Pseudomonas sp. ADP in soil [29]. In contrast, Pseudomonas sp. ADP degraded atrazine in 8 days in sediment slurries supplemented with $30 \mathrm{mg} \mathrm{L}^{-1}$ of atrazine [17]; that is, the initial concentration was below the $53-64 \mathrm{mg} \mathrm{L}^{-1}$. Thus, Pseudomonas sp. ADP can release atrazine from complexes with colloids and metal ions for degradation. However, in this study, the indigenous atrazine-degrading microbes in sediments may have degraded atrazine at concentrations above 53-64 $\mathrm{mg} \mathrm{L}^{-1}$, and somewhat overgrown Pseudomonas sp. ADP. Further, at atrazine concentrations above 53-64 $\mathrm{mg} \mathrm{L}^{-1}$, enzyme(s) releasing atrazine from the complexes with colloids and metal ions may not be required, and thus, a change in metabolism below this concentration may be required to degrade atrazine, which may take more than 10 days.

\subsection{Atrazine-Contaminated Aquifer Sediments and Remediation}

The results showed that indigenous microbes in atrazine-contaminated sediments could degrade atrazine above a high atrazine concentration of 10-64 $\mathrm{mg} \mathrm{L}^{-1}$ (Table 4). However, microbial atrazine degradation did not occur below $10-64 \mathrm{mg} \mathrm{L}^{-1}$. In the study aquifer, microbial atrazine degradation at concentrations below 10-64 $\mathrm{mg} \mathrm{L}^{-1}$ was observed only under aerobic conditions in the enrichment cultures of groundwater monitoring pipe A deposit slurries, of which four added microbes were isolated [6]. Degradation under aerobic conditions suggests oxidation associated with cytochrome P-450 $[7,12]$. In this study, the oxygen concentration in the liquid phase may have affected growth and respiration rate, but oxygen-dependent cellular functions were apparently not inhibited in sediment-water systems with liquid phase mixing. However, microbial atrazine degradation was not observed below 10-64 $\mathrm{mg} \mathrm{L}^{-1}$. Pseudomonas sp. ADP has also been known to degrade atrazine sediment slurries at concentrations below $30 \mathrm{mg} \mathrm{L}^{-1}$, regardless of oxygen [17], but this did not occur in this study. Based on the results, it can be estimated that at rather high concentrations, atrazine that leaked from a point source due to heavy rain or flooding may not be degraded microbially, as it flows with the water through the sediments into the groundwater. Saturated conditions caused by water prevent aerobic atrazine degradation, allowing Pseudomonas sp. ADP to degrade atrazine. However, Pseudomonas sp. ADP does not appear to belong to the indigenous population of the groundwater environment [40].

In long-term (180 days) degradation experiments, using low atrazine concentrations of $20 \mu \mathrm{g} \mathrm{L}^{-1}$ in water circulating columns at a flow rate of $2 \mathrm{~mL} \mathrm{~min}^{-1}$, atrazine dissipation rates have been estimated to be two to five times faster than in stagnant flasks [5], while pharmaceuticals dissipation was not enhanced at flow rates of $1.7-3.4 \mathrm{~mL} \mathrm{~min}^{-1}$ [65]. The short-term results of this study showed that at quite a high atrazine concentration below $10-18 \mathrm{mg} \mathrm{L}^{-1}$, high flow rate $\left(16.7 \mathrm{~mL} \mathrm{~min}^{-1}\right)$-induced changes in the sediment columns did not improve atrazine dissipation, apparently due to the good colloid formation ability [21-23], while the amount adsorbed to the sediments was low (about $50.1 \mu \mathrm{g}$ ). The atrazine distribution coefficient $K_{d}$, which is the ratio of atrazine adsorbed to that dissolved into the 
liquid phase, increases when the atrazine concentration decreases [66]. Therefore, in concentrations of $0.10 \mu \mathrm{g} \mathrm{L}^{-1}$, which is the European Union limit for atrazine in drinking water $[6,18]$, the greatest portion of atrazine is likely adsorbed to the sediment particles or bound to colloids and metal ions [22,50-52]. These strong interactions should be circumvented for remediation in groundwater sediments.

Although iron has been associated with the remediation of some pollutants [17,25], and the sediments of this study naturally contained about $12 \mathrm{mg} \mathrm{g}^{-1}$ of iron, it apparently did not significantly improve the chemical dissipation of colloid-bound atrazine. $\mathrm{NH}_{4}-\mathrm{N}$ and $\mathrm{NO}_{3}-\mathrm{N}$ concentrations below the detection limit suggest that nitrogen limited microbial growth in the sediments, and atrazine was used as the nitrogen source (Table 3). However, nitrogen deficiency was not a sufficient factor to cause microbes to release atrazine from colloids. Phosphorus has been reported to limit microbial growth in groundwater in Finland, and it could be another limiting factor in this study [32,67]. Natural mechanisms in the groundwater environment under stagnant conditions have been suggested to be insufficient to counteract the risk of atrazine accumulation [5], and the same conclusion can also be deduced from the results of this study under different conditions. Bioaugmentation alone or with biostimulation in the presented water-sediment systems could not enhance atrazine degradation. Atrazine is known to migrate rapidly to groundwater due to preferential flow and co-transport with colloidal matter [4]. The results support the suggestion that at relatively high concentrations, e.g., from point sources of pollution, atrazine bound to colloids can flow without dissipation through mineral sediment layers into groundwater; for example, during heavy rainfall or flooding. Although efficient water circulation under aerobic conditions enhanced atrazine release and activated microbes inherently degrading atrazine in a groundwater environment, atrazine levels eluting to groundwater may remain surprisingly high.

\section{Conclusions}

Water recycling improved atrazine $\left(100 \mathrm{mg} \mathrm{L}^{-1}\right)$ release from colloid-complex interactions and adsorption to sediments, after which it was degraded by microbes occurring inherently in the aquifer sediments from a depth of $13.6 \mathrm{~m}$, as the concentrations in the circulating water of the sediment columns (10-18 $\mathrm{mg} \mathrm{L}^{-1}$ ) were lower than in the liquid phases of sediment slurries (53-64 $\mathrm{mg} \mathrm{L}^{-1}$ ) (Table 4, Figure 1). Bioaugmentation with Pseudomonas sp. ADP, or four microbes isolated from groundwater deposit slurry mesocosms with atrazine degradation, did not significantly improve atrazine degradation in a 10-day experiment. Concomitant biostimulation with Na-citrate did not affect atrazine degradation. The microbial numbers increased simultaneously with atrazine degradation from $1.0 \times 10^{3}$ to $\geq 10^{8} \mathrm{cfu} \mathrm{mL}^{-1}$ in the slurries, and from $0.1-1.0 \times 10^{2}$ to $0.26-4.6 \times 10^{4} \mathrm{cfu} \mathrm{mL}^{-1}$ in the circulating water (Table 4 ). In the treatments without the added atrazine, microbial growth was activated less to $0.82-8.0 \times 10^{4} \mathrm{cfu} \mathrm{mL}^{-1}$ in the liquid phase of the slurries, and to $0.1-2.8 \times 10^{3} \mathrm{cfu} \mathrm{mL}^{-1}$ in the circulating water. Bacteria belonging to nine different genera were isolated from the cultivations; six belonged to phylum proteobacteria and three to actinobacteria, i.e., the diversity of cultured bacteria was low (Table 2). All genera of microbes cultivated from the liquid phase have been related to atrazine degradation under aerobic conditions, including Acinetobacter, Burkholderia, Methylobacterium, Pseudomonas, Rhodococcus, Sphingomonas, Streptomyces, Variovorax and Williamsia. Based on the results, it can be estimated that during heavy rain or flooding, at relatively high concentrations below 10-64 mg L ${ }^{-1}$, atrazine can flow through sediments into groundwater without dissipation.

Author Contributions: Conceptualization, M.H.K. and X.L.; methodology, X.L. and N.H.; writing-original draft preparation, X.L.; writing-review and editing, X.L., M.H.K. and N.H.; supervision, M.H.K. and N.H.; funding acquisition, N.H. and M.H.K. All authors have read and agreed to the published version of the manuscript.

Funding: This work was supported by the Maj and Tor Nessling Foundation, the Ministry of Agriculture and Forestry of Finland, Maa- ja Vesitekniikan tuki Ry, Lahti Aqua Ltd., the Finnish Cultural Foundation, the Kone Foundation and Shanghai Jiao Tong University.

Acknowledgments: Almalab personnel are acknowledged.

Conflicts of Interest: The authors declare no conflict of interest. 


\section{References}

1. Barrios, R.E.; Gaonkar, O.; Snow, D.; Li, Y.; Li, X.; Bartelt-Hunt, S.L. Enhanced biodegradation of atrazine at high infiltration rates in agricultural soils. Environ. Sci. Proc. Imp. 2019, 21, 999-1010. [CrossRef]

2. Wang, Y.; Lai, A.; Latino, D.; Fenner, K.; Helbling, D.E. Evaluating the environmental parameters that determine aerobic biodegradation half-lives of pesticides in soil with a multivariable approach. Chemosphere 2018, 209, 430-438. [CrossRef] [PubMed]

3. Salazar-Ledesma, M.; Prado, B.; Zamora, O.; Siebe, C. Mobility of atrazine in soils of a wastewater irrigated maize field. Agr. Ecosyst. Environ. 2018, 255, 73-83. [CrossRef]

4. Arias-Estévez, M.; López-Periago, E.; Martínez-Carballo, E.; Simal-Gándara, J.; Mejuto, J.-C.; García-Río, L. The mobility and degradation of pesticides in soils and the pollution of groundwater Resources. Agr. Ecosyst. Environ. 2008, 123, 247-260. [CrossRef]

5. Schwab, A.P.; Splichal, P.A.; Banks, M.K. Persistence of atrazine and alachlor in ground water aquifers and soil. Water Air Soil Poll. 2006, 171, 203-235. [CrossRef]

6. Talja, K.M.; Kaukonen, S.; Kilpi-Koski, J.; Malin, I.; Kairesalo, T.; Romantschuk, M.; Tuominen, J.; Kontro, M.H. Atrazine and terbutryn degradation in deposits from groundwater environment within the boreal region in Lahti, Finland. J. Agric. Food Chem. 2008, 56, 11962-11968. [CrossRef] [PubMed]

7. Ralebitso, T.K.; Senior, E.; van Verseveld, H.W. Microbial aspects of atrazine degradation in natural environments. Biodegradation 2002, 13, 11-19. [CrossRef]

8. Derakhshan, Z.; Mahvi, A.H.; Ehrampoush, M.H.; Mazloomi, S.M.; Faramarzian, M.; Dehghani, M.; Yousefinejad, S.; Ghaneian, M.T.; Abtahi, S.M. Studies on influence of process parameters on simultaneous biodegradation of atrazine and nutrients in aquatic environments by a membrane photobioreactor. Environ. Res. 2018, 161, 599-608. [CrossRef]

9. Tonelli Fernandes, A.F.; Braz, V.S.; Bauermeister, A.; Rizzato Paschoal, J.A.; Lopes, N.P.; Stehling, E.G. Degradation of atrazine by Pseudomonas sp. and Achromobacter sp. isolated from Brazilian agricultural soil. Int. Biodeterior. Biodegrad. 2018, 130,17-22. [CrossRef]

10. Chan, C.Y.; Tao, S.; Dawson, R.; Wong, P.K. Treatment of atrazine by integrating photocatalytic and biological processes. Environ. Pollut. 2004, 131, 45-54. [CrossRef]

11. Gao, J.; Song, P.; Wang, G.; Wang, J.; Zhu, L.; Wang, J. Responses of atrazine degradation and native bacterial community in soil to Arthrobacter sp. strain HB-5. Ecotox. Environ. Safe. 2018, 159, 317-323. [CrossRef] [PubMed]

12. Copley, S.D. Evolution of efficient pathways for degradation of anthropogenic chemicals. Nat. Chem. Biol. 2009, 5, 559-566. [CrossRef] [PubMed]

13. Stipičević, S.; Galzina, N.; Udiković-Kolić, N.; Jurina, T.; Mendaš, G.; Dvoršćak, M.; Petrić, I.; Barić, K.; Drevenkar, V. Distribution of terbuthylazine and atrazine residues in crop-cultivated soil: The effect of herbicide application rate on herbicide persistence. Geoderma 2015, 259-260, 300-309. [CrossRef]

14. Singh, S.; Kumar, V.; Chauhan, A.; Datta, S.; Wani, A.B.; Singh, N.; Singh, J. Toxicity, degradation and analysis of the herbicide atrazine. Environ. Chem. Lett. 2018, 16, 211-237. [CrossRef]

15. He, H.; Liu, Y.; You, S.; Liu, J.; Xiao, H.; Tu, Z. A review on recent treatment technology for herbicide atrazine in contaminated environment. Int. J. Environ. Res. Public Health 2019, 16, 5129. [CrossRef]

16. Casasso, A.; Tosco, T.; Bianco, C.; Bucci, A.; Sethi, R. How can we make pump and treat systems more energetically sustainable? Water 2020, 12, 67. [CrossRef]

17. Kerminen, K.; Le Moël, R.; Harju, V.; Kontro, M.H. Influence of organic matter, nutrients, and cyclodextrin on microbial and chemical herbicide and degradate dissipation in subsurface sediment slurries. Sci. Total Environ. 2018, 618, 1449-1458. [CrossRef]

18. Fan, X.; Song, F. Bioremediation of atrazine: Recent advances and promises. J. Soils Sediments 2014, 14, 1727-1737. [CrossRef]

19. Ciampi, P.; Esposito, C.; Papini, M.P. Hydrogeochemical model supporting the remediation strategy of a highly contaminated industrial site. Water 2020, 11, 1371. [CrossRef]

20. Gentry, T.; Rensing, C.; Pepper, I. New approaches for bioaugmentation as a remediation technology. Crit. Rev. Environ. Sci. Technol. 2004, 34, 447-494. [CrossRef]

21. Kerminen, K.; Kontro, M.H. Sonication effect on atrazine dissipation in vadose zone sediment slurries. Environments 2017, 4, 18. [CrossRef] 
22. de Jonge, L.W.; Kjaergaard, C.; Moldrup, P. Colloids and colloid-facilitated transport of contaminants in soils: An introduction. Vadose Zone J. 2004, 3, 321-325. [CrossRef]

23. Meng, Z.; Carper, R. Effects of hydration on the molecular structure of metal ion-atrazine dimer complexes: A MOPAC (PM3) study. J. Mol. Struc. THEOCHEM 2000, 531, 89-98. [CrossRef]

24. Zhou, Z.; Liu, X.; Sun, K.; Lin, C.; Ma, J.; He, M.; Ouyang, W. Persulfate-based advanced oxidation processes (AOPs) for organic contaminated soil remediation: A review. Chem. Eng. J. 2019, 372, 836-851. [CrossRef]

25. Kerminen, K.; Salovaara, V.; Kontro, M.H. A zero-valent iron and organic matter micture enhances herbicide and herbicide degradation product removal in subsurface waters. J. Environ. Sci. 2017, 57, 411-417. [CrossRef] [PubMed]

26. dos Santos, E.V.; Sáez, C.; Cañizares, P.; Martínez-Huitle, C.A.; Rodrigo, M.A. Reversible electrokinetic adsorption barriers for the removal of atrazine and oxyfluorfen from spiked soils. J. Hazard. Mater. 2017, 322, 413-420. [CrossRef]

27. Grajales-Mesa, S.J.; Malina, G. Pilot-scale evaluation of a permeable reactive barrier with compost and brown coal to treat groundwater contaminated with trichloroethylene. Water 2019, 11, 1922. [CrossRef]

28. Martinez, B.; Tomkins, J.; Wackett, L.P.; Wing, R.; Sadowsky, M.J. Complete nucleotide sequence and organization of the atrazine catabolic plasmid pADP-1 from Pseudomonas sp. strain ADP. J. Bacteriol. 2001, 183, 5684-5697. [CrossRef]

29. Mandelbaum, R.T.; Allan, D.L.; Wackett, L.P. Isolation and characterization of a Pseudomonas sp. that mineralizes the s-triazine herbicide atrazine. Appl. Environ. Microb. 1995, 61, 1451-1457. [CrossRef]

30. Balkwill, D.L.; Ghiorse, W.C. Characterization of subsurface bacteria associated with two shallow aquifers in Oklahoma. Appl. Environ. Microb. 1985, 50, 580-588. [CrossRef]

31. Fahy, A.; McGenity, T.J.; Timmis, K.N.; Ball, A.S. Heterogeneous aerobic benzene-degrading communities in oxygen-depleted groundwaters. FEMS Microbiol. Ecol. 2006, 58, 260-270. [CrossRef]

32. Mattsson, M.K.; Liu, X.; Yu, D.; Kontro, M.H. Depth, soil type, water table, and site effects on microbial community composition in sediments of pesticide-contaminated aquifer. Environ. Sci. Pollut. Res. 2015, 22, 10263-10279. [CrossRef] [PubMed]

33. LECO Corp. Total Organic Carbon and Nitrogen in Soils; Organic Application Note 203-821-165; LECO Corp.: St. Joseph, MI, USA, 2003.

34. SFS 5505. Determination of Inorganic and Organic Nitrogen in Wastewater. Modified Kjeldahl Method; Finnish Standards Association SFS: Helsinki, Finland, 1988.

35. Water Quality. Determination of Dissolved Fluoride, Chloride, Nitrite, Orthophosphate, Bromide, Nitrate and Sulphate Ions, Using Liquid Chromatography of Ions; SFS-EN ISO 10304-1, Part 1: Method for Water with Low Contamination; Finnish Standards Association SFS: Helsinki, Finland, 1995.

36. Water Quality. Determination of Dissolved Anions by Liquid Chromatography of Ions; SFS-EN ISO 10304-2; Part 2: Determination of Bromide, Chloride, Nitrate, Nitrite, Orthophosphate and Sulphate in Wastewater; Finnish Standards Association SFS: Helsinki, Finland, 1997.

37. Water Quality. Determination of 33 Elements by Inductively Coupled Plasma Atomic Emission Spectroscopy; ISO 11885; Finnish Standard Association: Helsinki, Finland, 1996.

38. Soil Quality. Determination of Trace Elements in Extracts of Soil by Inductively Coupled Plasma-Atomic Emission Spectrometry (ICP-AES); SFS-ISO 22036; International Standard Organization: Geneva, Switzerland, 2005.

39. General Requirements for the Competence of Testing and Calibration Laboratories; SFS-EN ISO/IEC 17025; Finnish Standards Association SFS: Helsinki, Finland, 2005.

40. Liu, X.; Ecarnot, M.; Kontro, M.H. The physicochemical conditions of isolation source determine the occurrence of Pseudomonas fluorescens group species. Ann. Microbiol. 2015, 65, 2363-2377. [CrossRef]

41. Edwards, U.; Rogall, T.; Blöcker, H.; Emde, M.; Böttger, E.C. Isolation and direct complete nucleotide determination of entire genes. Characterization of a gene coding for $16 \mathrm{~S}$ ribosomal RNA. Nucleic Acids Res. 1989, 17, 7843-7853. [CrossRef] [PubMed]

42. Hui, N.; Jumpponen, A.; Niskanen, T.; Liimatainen, K.; Jones, K.L.; Koivula, T.; Romantschuk, M.; Strömmer, R. EcM fugal community structure, but not diversity, altered in a Pb-contaminated shooting range in a boreal coniferous forest site in Southern Finland. FEMS Microbiol. Ecol. 2011, 76, 121-132. [CrossRef]

43. Pukkila, V.; Gustafsson, J.; Tuominen, J.; Aallonen, A.; Kontro, M.H. The most-probable-number enumeration of dichlobenil and 2,6-dichlorobenzamide (BAM) degrading microbes in Finnish aquifers. Biodegradation 2009, 20, 679-686. [CrossRef] 
44. Pukkila, V.; Kontro, M.H. Dichlobenil and 2,6-dichlorobenzamide (BAM) dissipation in topsoil and deposits from groundwater environment within the boreal region in southern Finland. Environ. Sci. Pollut. Res. 2014, 21, 3732-3739. [CrossRef]

45. Gutell, R.R.; Larsen, N.; Woese, C.R. Lessons from an evolving rRNA: 16S and 23S rRNA structures from a comparative perspective. Microbiol. Rev. 1994, 58, 10-26. [CrossRef]

46. Tomlin, C.D.S. The Pesticide Manual, 12th ed.; The British Crop Protection Council: Surrey, UK, 2000.

47. Geyer, H.; Viswanathan, R.; Freitag, D.; Korte, F. Relationship between water solubility of organic chemicals and their bioaccumulation by the alga Chlorella. Chemosphere 1981, 10, 1307-1313. [CrossRef]

48. Holtze, M.S.; Sørensen, S.R.; Sørensen, J.; Aamand, J. Microbial degradation of the benzonitrile herbicides dichlobenil, bromoxynil and ioxynil in soil and subsurface environments-Insights into degradation pathways, persistent metabolites and involved degrade organisms. Environ. Pollut. 2008, 154, 155-168. [CrossRef]

49. Prosen, H.; Zupančič-Kralj, L. Evaluation of photolysis and hydrolysis of atrazine and its first degradation products in the presence of humic acids. Environ. Pollut. 2005, 133, 517-529. [CrossRef] [PubMed]

50. Nasser, A.; Mingelgrin, U. Mechanochemistry: A review of surface reactions and environmental applications. Appl. Clay Sci. 2012, 67-68, 141-150. [CrossRef]

51. Shin, J.Y.; Cheney, M.A. Abiotic transformation of atrazine in aqueous suspension of four synthetic manganese oxides. Colloid. Surf. A 2004, 242, 85-92. [CrossRef]

52. Mata-Sandoval, J.C.; Karns, J.; Torrents, A. Influence of rhamnolipids and triton X-100 on the biodegradation of three pesticides in aqueous phase and soil slurries. J. Agric. Food Chem. 2001, 49, 3296-3303. [CrossRef]

53. Lipponen, M.T.T.; Suutari, M.H.; Martikainen, P.J. Occurrence of nitrifying bacteria and nitrification in Finnish drinking water distribution systems. Water Res. 2002, 36, 4319-4329. [CrossRef]

54. Gregory, S.P.; Maurice, L.D.; West, J.M.; Gooddy, D.C. Microbial communities in UK aquifers: Current understanding and future research needs. Q. J. Eng. Geol. Hydrogeol. 2014, 47, 145-157. [CrossRef]

55. Balkwill, D.L.; Murphy, E.M.; Fair, D.M.; Ringelberg, D.B.; White, D.C. Microbial communities in high and low recharge environments: Implications for microbial transport in the vadose zone. Microb. Ecol. 1998, 35, 156-171. [CrossRef]

56. Ros, M.; Goberna, M.; Moreno, J.L.; Hernandez, T.; García, C.; Insam, H.; Pascual, J.A. Molecular and physiological bacterial diversity of a semi-arid soil contaminated with different levels of formulated atrazine. Appl. Soil Ecol. 2006, 34, 93-102. [CrossRef]

57. Feakin, S.J.; Gubbins, B.; McGhee, I.; Shaw, L.J.; Burns, R.G. Inoculation of granular activated carbon with s-triazine-degrading bacteria for water treatment at pilot-scale. Water Res. 1995, 29, 1681-1688. [CrossRef]

58. Martin-Laurent, F.; Barrès, B.; Wagschal, I.; Piutti, S.; Devers, M.; Soulas, G.; Philippot, L. Impact of the maize rhizosphere on the genetic structure, the diversity and the atrazine-degrading gene composition of cultivable atrazine-degrading communities. Plant Soil 2006, 282, 99-115. [CrossRef]

59. Fang, H.; Lian, J.; Wang, H.; Cai, L.; Yu, Y. Exploring bacterial community structure and function associated with atrazine biodegradation in repeatedly treated soils. J. Hazard. Mater. 2015, 286, 457-465. [CrossRef] [PubMed]

60. Frascari, D.; Zanaroli, G.; Danko, A.S. In situ aerobic cometabolism of chlorinated solvents: A review. J. Hazard. Mater. 2015, 283, 382-399. [CrossRef] [PubMed]

61. Bruell, C.J.; Marley, M.C.; Hopkins, H.H. American petroleum institute in situ air sparging database. J. Soil Contam. 1997, 6, 169-185. [CrossRef]

62. Elomari, M.; Coroler, L.; Hoste, B.; Gillis, M.; Izard, D.; Leclerc, H. DNA Relatedness among Pseudomonas strains isolated from natural mineral waters and proposal of Pseudomonas veronii sp. nov. Int. J. Syst. Bacteriol. 1996, 46, 1138-1144. [CrossRef]

63. Schloss, P.D.; Allen, H.K.; Klimowicz, A.K.; Mlot, C.; Gross, J.A.; Savengsuksa, S.; McEllin, J.; Clardy, J.; Ruess, R.W.; Handelsman, J. Psychrotrophic strain of Janthinobacterium lividum from a cold Alaskan soil produces prodigiosin. DNA Cell Biol. 2010, 29, 533-541. [CrossRef]

64. Klinger, E.G.; James, R.R.; Youssef, N.N.; Welker, D.L. A multi-gene phylogeny provides additional insight into the relationships between several Ascosphaera species. J. Invertebr. Pathol. 2013, 112, 41-48. [CrossRef]

65. Kiecak, A.; Breuer, F.; Stumpp, C. Column experiments on sorption coefficients and biodegradation rates of selected pharmaceuticals in three aquifer sediments. Water 2020, 12, 14. [CrossRef] 
66. Arias-Estévez, M.; Soto-González, B.; López-Periago, E.; Cancho-Grande, B.; Simal-Gándara, J. Atrazine Sorption Dynamics in Acid-Surface Soils. Bull. Environ. Contam. Toxicol. 2005, 75, 264-271. [CrossRef]

67. Keinanen, M.M.; Korhonen, L.K.; Lehtola, M.J.; Miettinen, I.T.; Martikainen, P.J.; Vartiainen, T.; Suutari, M.H. The microbial community structure of drinking water biofilms can be affected by phosphorus availability. App. Environ. Microb. 2002, 68, 434-439. [CrossRef]

(C) 2020 by the authors. Licensee MDPI, Basel, Switzerland. This article is an open access article distributed under the terms and conditions of the Creative Commons Attribution (CC BY) license (http://creativecommons.org/licenses/by/4.0/). 